Bangl. J. Vet. Med. (2008). 6 (1): 115-119

\title{
EFFECTS OF GARLIC, TURMERIC AND BETEL LEAF AGAINST GASTROINTESTINAL NEMATODES IN CATTLE
}

\author{
M. R. Amin, M. Mostofa, M. A. Awal and M. A. Sultana
}

Department of Pharmacology, Faculty of Veterinary Science, Bangladesh Agricultural University, Mymensingh-2202, Bangladesh

\begin{abstract}
The experiment was conducted in the Department of Pharmacology, Faculty of Veterinary Science, Bangladesh Agricultural University, Mymensingh, for a period of 28 days to study the effects of garlic (Allium sativum, Linn., @100mg/kg bwt.), turmeric (Curcuma longa, Linn., @100mg/kg bwt.) and betel leaf (Piper betle, Linn., @100mg/kg bwt.) against natural gastrointestinal nematodes in cattle. The effects of garlic, turmeric and betel leaf on some hematological parameters (TEC, Hb, PCV and TLC), biochemical parameters (ALT and AST) and clinical parameter (body weight) were also observed. Twenty four (24) naturally parasitized cattle of BAU Dairy Farm, Mymensingh were randomly divided into four groups, each consisting of six (6) cattle. Water extract of bulbs of garlic were administered orally to the cattle of group A. Cattle of group B received orally water extract of rhizome of turmeric. Cattle of group $\mathrm{C}$ were treated orally with leaves of betel leaf. Cattle of group D was kept as infected control group. Fecal samples, body weight, hematological and biochemical parameters were examined before treatment and on $3^{\text {rd }}, 10^{\text {th }}, 17^{\text {th }}$ and $28^{\text {th }}$ day. A significant $(\mathrm{p}<0.01)$ reduction of EPG count was found following administration of garlic (20.41-40.81\%), turmeric (6.09-19.27\%) and betel leaf (2.91-9.8\%) in cattle. The EPG count of the control group (D) were significantly $(\mathrm{p}<0.01)$ increased up to the last day of experimental period. After treatment with garlic and turmeric total erythrocyte count (TEC), hemoglobin (Hb) content and packed cell volume (PCV) were gradually increased significantly ( $<0.01$ and $\mathrm{p}<0.05$ ) in cattle. Conversely, the total leukocyte count (TLC) were decreased significantly ( $\mathrm{p}<0.01$ and $\mathrm{p}<0.05$ ) in treated cattle. On the other hand, TEC, Hb content and PCV were gradually increased significantly ( $<<0.01$ and $\mathrm{p}<0.05$ ) on day 3 and day 10 in betel leaf treated cattle but decreased on $17^{\text {th }}$ and $28^{\text {th }}$ day. Conversely, the total leukocyte count (TLC) were decreased significantly $(\mathrm{p}<0.01$ and $\mathrm{p}<0.05)$ on day 3 and day 10 in betel leaf treated cattle but increased significantly $(\mathrm{p}<0.01)$ on $17^{\text {th }}$ and $28^{\text {th }}$ day. The alanine aminotransferase (ALT) and aspartate aminotransferase (AST) level were not significantly changed in the cattle. The body weight was increased significantly $(\mathrm{p}<0.01$ and $\mathrm{p}<0.05)$ in garlic, turmeric and betel leaf treated cattle. On the other hand, body weight was decreased in untreated control group. The present study reveals that water extracts of garlic were moderately effective and turmeric and betel leaf were relatively less effective against gastrointestinal nematodes in cattle.
\end{abstract}

Key words: Nematodes, garlic, turmeric, betel, leaf, cattle

\section{INTRODUCTION}

Parasitism is an important limiting factor that responsible for deteriorating the health and productivity of livestock. The agro-ecological and geo-climatic conditions of Bangladesh are highly favorable for the growth and multiplication of parasites. Among the parasitic diseases, gastrointestinal nematodes such as Haemonchus spp., Trichostrongylus spp., Cooperia spp., Oesophagostomum spp., Trichuris spp. and Strongyloides spp. are most common in Bangladesh (Qadir, 1981; Rahman and Mondal, 1983). The greatest losses associated with nematode infections are sub-clinical, and economic assessments have showed that financial costs of internal parasitism are enormous (Preston and Allonby, 1979; McLeod, 1995). Control of parasitic diseases has been mainly based on regular anthelmintic treatment in Bangladesh. However, as these are very expensive and unavailable to farmers in rural areas, livestock producers are not interested to use these anthelmintics. Furthermore, some serious disadvantages of using those anthelmintics, notably the development of resistance to helminth parasites (Waller and Prichard, 1985; Lans and Brown, 1998) against various anthelmintic compounds and classes, as well as their residues and toxicity problems (Kaemmerer and Butenkotter, 1973) poses hazards to livestock development. Medicinal plants are one of the most important natural resources of a country. 
World Health Organization (WHO, 1993) has recognized the necessity for investigation and mobilization of ancient medicinal practices to fulfill the primary health care systems of the man and animals, and realizes that the traditional system of medicine may play an important role in the development of livestock of the third world countries. Plant remedies were also extensively used as anthelmintics in the developed world before the era of broad spectrum synthetic drugs (British Veterinary Codex, 1953). Many currently available therapeutic compounds are plant derived and/or synthetic analogues derived from those compounds (Farnsworth et al., 1985). For these reasons, interest in the screening of medicinal plants for their anthelmintic activity has remained of great scientific interest despite extensive use of synthetic chemicals in modern clinical practices all over the world (Akhtar et al., 2000). The present study was undertaken to evaluate the efficacy of garlic, turmeric and betel leaf against gastrointestinal nematodes on the basis of fecal egg count in cattle. The effects of garlic, turmeric and betel leafs on hematological parameters (TEC, Hb, PCV and TLC), biochemical parameters (ALT and AST) and clinical parameter (body weight) were also determined in this study.

\section{MATERIALS AND METHODS}

The experiment was performed in the Department of Pharmacology, Faculty of Veterinary Science, Bangladesh Agricultural University, Mymensingh, Bangladesh. Bangladesh Agricultural University Dairy Farm was selected as the site for this study. The research was carried out during the period from $1^{\text {st }}$ June, 2005 to $28^{\text {th }}$ June, 2005. Fifty cattle (2-3 years approximately) were selected for this study which were suspected to be suffering from natural gastrointestinal nematodes infection and they were marked at the ears by the numbered tag. Examination of fecal samples for gastrointestinal nematodes egg counts by floatation method (Rahman et al., 1996) were carried out over a week prior to commencement of treatment. On the basis of fecal sample examination results, 24 cattle of both sexes infected with gastrointestinal nematodes were selected for this study and randomly divided into four groups, each group consisting of six (6) cattle.

Group A : Water extract of garlic (Allium sativum, Linn.) bulbs was administered @100mg/kg bwt orally.

Group B : Water extract of turmeric (Curcuma longa, Linn.) rhizome was administered @100mg/kg bwt orally.

Group C : Water extract of Betel leaf (Piper betle, Linn.) leaves was administered @100mg/kg bwt orally. Group D : $\quad$ Used as untreated control group.

The fecal sample from all groups were examined by egg counting McMaster method as described by Soulsby (1986) before treatment (day 0) and at $3^{\text {rd }}, 10^{\text {th }}, 17^{\text {th }}$ and $28^{\text {th }}$ day of post-treatment. Eggs per gram (EPG) of feces were recorded. Blood samples were collected from the jugular vein of each cattle at different time intervals as mentioned above. Various hematological parameters (TEC, Hb, PCV and TLC) were measured following the method of Coffin (1953). Biochemical (ALT and AST) parameters were also examined by auto-analyzer (Reflotron ${ }^{\circledR}$ Plus) according to the method described by Deneke and Rittersdorf (1984 and 1985). To determine the body weight gain or loss of treated and untreated control groups, the main body weight was taken on day 0 (pretreatment) and on $3^{\text {rd }}, 10^{\text {th }}, 17^{\text {th }}$ and $28^{\text {th }}$ day of experimental period of cattle (Samad, 2001). Collected data were statistically analyzed between normal and treated values by Student's t-test by using the computer statistical package programme of Microsoft Excel.

\section{RESULTS AND DISCUSSION}

The results of the efficacy of garlic, turmeric and betel leaf against gastrointestinal nematodes in cattle are shown in Table 1. A significant $(p<0.01)$ reduction of EPG counts were found on $3^{\text {rd }}, 10^{\text {th }}, 17^{\text {th }}$ and $28^{\text {th }}$ day following garlic and turmeric treated cattle of group A and B, respectively. However, betel leaf treated cattle showed significant $(\mathrm{p}<0.01)$ reduction on day 3 and day 10 in group D. On $17^{\text {th }}$ and $28^{\text {th }}$ day, the EPG counts were increased significantly $(\mathrm{p}<0.01)$ following betel leaf treatment. In conformity to the present findings, Mostofa and Amin (2005) examined the effects of $10 \%$ water extract of garlic against gastrointestinal nematodes of sheep. A significant reduction of EPG count was found on $7^{\text {th }}, 14^{\text {th }}, 21^{\text {st }}$ and $28^{\text {th }}$ day of garlic $(44.01 \%$, 43.29\%, 40.88\% and 38.70\%, respectively) treated sheep. Likewise, Rahman (2002) found the anthelmintic efficacy of water extract of garlic and betel leaves was $60 \%$ and $58 \%$, respectively in goat on 21 days of posttreatment. 
Table 1. Efficacy of garlic, turmeric and betel leaf against natural gastrointestinal nematodes in cattle

\begin{tabular}{|c|c|c|c|c|c|c|c|c|c|c|}
\hline \multirow[t]{3}{*}{ Groups } & \multirow[t]{3}{*}{ Treatment } & \multirow{3}{*}{$\begin{array}{l}\text { Pre-treatment } \\
\text { '0' day } \\
\text { EPG }\end{array}$} & \multicolumn{8}{|c|}{ Post treatment } \\
\hline & & & \multicolumn{2}{|l|}{$3^{\text {rd }}$ day } & \multicolumn{2}{|l|}{$10^{\text {th }}$ day } & \multicolumn{2}{|l|}{$17^{\text {th }}$ day } & \multicolumn{2}{|l|}{$28^{\text {th }}$ day } \\
\hline & & & EPG & $\begin{array}{l}\text { EPG } \\
\text { increase/ } \\
\text { decrease } \\
(\%)\end{array}$ & EPG & $\begin{array}{l}\text { EPG } \\
\text { increase/ } \\
\text { decrease } \\
(\%)\end{array}$ & EPG & $\begin{array}{l}\text { EPG } \\
\text { increase/ } \\
\text { decrease } \\
(\%)\end{array}$ & EPG & $\begin{array}{l}\text { EPG } \\
\text { increase/ } \\
\text { decrease } \\
(\%)\end{array}$ \\
\hline A & Garlic & $\begin{array}{l}1333 \\
\pm 274.84\end{array}$ & $\begin{array}{l}900 * * \\
\pm 192.02\end{array}$ & +32.48 & $\begin{array}{l}789 * * \\
\pm 129.33\end{array}$ & +40.81 & $\begin{array}{l}972 * * \\
\pm 210.24\end{array}$ & +27.08 & $\begin{array}{l}1061^{* *} \\
\pm 254.24\end{array}$ & +20.41 \\
\hline B & Turmeric & $\begin{array}{l}1183 \\
\pm 180.95\end{array}$ & $\begin{array}{l}1039 * * \\
\pm 135.82\end{array}$ & +12.17 & $\begin{array}{l}955^{* *} \\
\pm 136.08\end{array}$ & +19.27 & $\begin{array}{l}1078 * * \\
\pm 137.73\end{array}$ & +8.88 & $\begin{array}{l}1111^{* *} \\
\pm 150.01\end{array}$ & +6.09 \\
\hline $\mathrm{C}$ & Betel leaf & $\begin{array}{l}1133 \\
\pm 165.95\end{array}$ & $\begin{array}{l}1022^{* *} \\
\pm 158.81\end{array}$ & +9.80 & $\begin{array}{l}1100 * * \\
\pm 148.83\end{array}$ & +2.91 & $\begin{array}{l}1200 * * \\
\pm 157.58\end{array}$ & -5.91 & $\begin{array}{l}1289 * * \\
\pm 161.26\end{array}$ & -13.77 \\
\hline $\mathrm{D}$ & Control & $\begin{array}{l}1050 \\
\pm 269.81\end{array}$ & $\begin{array}{l}1100^{* *} \\
\pm 279.91\end{array}$ & -4.76 & $\begin{array}{l}1211^{* *} \\
\pm 276.99\end{array}$ & -15.33 & $\begin{array}{l}1350 * * \\
\pm 236.20\end{array}$ & -28.57 & $\begin{array}{l}1500 * * \\
\pm 237.67\end{array}$ & -42.86 \\
\hline
\end{tabular}

The above values represent the Mean \pm standard deviation (SD) of 6 cattle, ** = Significant at 1 per cent level $(\mathrm{p}<0.01)$, * = Significant at 5 per cent level $(\mathrm{p}<0.05)$, ‘+' = Decrease, '-' = Increase.

The results of the effect of garlic, turmeric and betel leaf on different hematological parameters are shown in the Table 2. Garlic and turmeric significantly $(\mathrm{p}<0.01$ and $\mathrm{p}<0.05)$ increased total erythrocyte count (TEC) in cattle of group A and B, respectively. TEC was increased significantly $(\mathrm{p}<0.01$ and $\mathrm{p}<0.05)$ on day 3 and day 10 in betel leaf treated cattle of group C. On $17^{\text {th }}$ and $28^{\text {th }}$ day, the TEC was decreased significantly $(p<0.01)$ following betel leaf treatment. Garlic and turmeric increased significantly $(p<0.01$ and $p<0.05$ ) hemoglobin $\mathrm{Hb}$ content in cattle of group A and B, respectively. Hb content was increased on day 3 and day 10 in betel leaf treated cattle of group C. On $17^{\text {th }}$ and $28^{\text {th }}$ day, the $\mathrm{Hb}$ content were decreased significantly $(\mathrm{p}<0.01)$ following betel leaf treatment. Garlic and turmeric increased significantly $(\mathrm{p}<0.01$ and $\mathrm{p}<0.05)$ packed cell volume (PCV) in cattle of group A and B, respectively. PCV was increased significantly $(\mathrm{p}<0.05)$ on day 3 and day 10 in betel leaf treated cattle of group C. On $17^{\text {th }}$ and $28^{\text {th }}$ day, the PCV was decreased following betel leaf treatment. Conversely, garlic and turmeric decreased significantly $(\mathrm{p}<0.01$ and $\mathrm{p}<0.05)$ total leukocyte count (TLC) in cattle of group A and B, respectively. TLC was decreased significantly (p < 0.01) on day 3 and day 10 in betel leaf treated cattle of group C. On $17^{\text {th }}$ and $28^{\text {th }}$ day, the TLC was increased significantly $(p<0.01)$ following betel leaf treatment. The present finding was also in agreement with the work of Rahman (2002). He observed water extract of garlic (@2 gm/kg bwt.) and betel leaf (@2 gm/kg bwt.) increased TEC, Hb content and PCV and decreased TLC on $21^{\text {st }}$ day of post-treatment in goat. Similar observations also reported due to $10 \%$ water extract of garlic in sheep by Mostofa and Amin (2005).

The results of the effect of garlic, turmeric and betel leaf on biochemical parameters are shown in the Table 3 . The alanine aminotransferase (ALT) and aspartate aminotransferase (AST) level were not significantly changed in the cattle. These findings cannot be compared due to lack of similar published reports.

The effects of garlic, turmeric and betel leaf on body weight in cattle are shown in Table 4. Garlic, turmeric and betel leaf significantly ( $\mathrm{p}<0.01$ and $\mathrm{p}<0.05$ ) increased body weight in group A, B and C, respectively. These results were agreeable with the findings of Mostofa and Amin (2005) for garlic in sheep.

It may be concluded that water extracts of garlic was moderately effective and turmeric and betel leaf were relatively less effective against gastrointestinal nematode infections in cattle. Of course the present study is a preliminary work on the medicinal plants in cattle in Bangladesh. However, further studies on its pharmacokinetic and toxic effects if any should be carried out before extensive field use in Bangladesh. 
M. R. Amin and others

Table 2. Changes in hematological parameters in cattle at different intervals after treatment with garlic, turmeric and betel leaf

\begin{tabular}{|lllll|}
\hline Days after treatment & $\begin{array}{l}\text { Garlic } \\
\text { treatment } \\
\text { (Group A) }\end{array}$ & $\begin{array}{l}\text { Turmeric } \\
\text { treatment } \\
\text { (Group B) }\end{array}$ & $\begin{array}{l}\text { Betel leaf } \\
\text { treatment } \\
\text { (Group C) }\end{array}$ & $\begin{array}{l}\text { Untreated } \\
\text { infected control } \\
\text { (Group D) }\end{array}$ \\
\hline Day 0 & & & & \\
TEC (million/cu.mm.) & $8.56 \pm 0.93$ & $8.99 \pm 0.56$ & $9.02 \pm 0.57$ & $9.31 \pm 0.71$ \\
Hb content (gm\%) & $8.97 \pm 1.15$ & $9.60 \pm 0.89$ & $9.90 \pm 0.77$ & $10.43 \pm 1.14$ \\
PCV (\%) & $30.83 \pm 2.32$ & $32.00 \pm 1.41$ & $32.33 \pm 1.37$ & $33.17 \pm 1.94$ \\
TLC (thousand/cu.mm.) & $10.28 \pm 1.27$ & $9.43 \pm 0.88$ & $9.22 \pm 0.91$ & $9.11 \pm 1.16$ \\
Day 3 & & & & \\
TEC (million/cu.mm.) & $8.60^{* *} \pm 0.93$ & $9.02^{*} \pm 0.58$ & $9.04^{*} \pm 0.56$ & $9.24^{* *} \pm 0.67$ \\
Hb content (gm \%) & $9.13^{*} \pm 1.03$ & $9.73^{*} \pm 0.92$ & $9.93 \pm 0.70$ & $10.20^{* *} \pm 1.13$ \\
PCV (\%) & $31.17 \pm 1.94$ & $32.33 \pm 1.03$ & $32.50 \pm 1.38$ & $32.67^{*} \pm 1.75$ \\
TLC (thousand/cu.mm) & $10.18^{*} \pm 1.26$ & $9.38^{*} \pm 0.84$ & $9.13^{* *} \pm 0.89$ & $9.19^{*} \pm 1.14$ \\
Day 10 & & & & \\
TEC (million/cu.mm.) & $8.84^{* *} \pm 0.89$ & $9.13^{* *} \pm 0.59$ & $9.08^{* *} \pm 0.56$ & $9.06^{* *} \pm 0.67$ \\
Hb content (gm \%) & $9.80^{* *} \pm 1.06$ & $10.17^{* *} \pm 0.94$ & $10.03 \pm 0.60$ & $9.50^{* *} \pm 1.01$ \\
PCV (\%) & $32.00^{* *} \pm 1.79$ & $33.00^{*} \pm 0.63$ & $33.17^{*} \pm 1.17$ & $32.00^{*} \pm 1.67$ \\
TLC (thousand/cu.mm.) & $10.01^{* *} \pm 1.21$ & $9.27^{* *} \pm 0.80$ & $9.05^{* *} \pm 0.90$ & $9.48^{* *} \pm 1.12$ \\
Day 17 & & & & \\
TEC (million/cu.mm.) & $9.00^{* *} \pm 0.87$ & $9.34^{*} \pm 0.65$ & $8.99^{* *} \pm 0.56$ & $8.88^{* *} \pm 0.64$ \\
Hb content (gm \%) & $10.33^{* *} \pm 0.99$ & $10.63^{* *} \pm 0.90$ & $9.70^{* *} \pm 0.65$ & $8.60^{* *} \pm 0.65$ \\
PCV (\%) & $32.67^{* *} \pm 1.63$ & $33.33^{* *} \pm 1.03$ & $32.16 \pm 0.72$ & $30.83^{* *} \pm 2.04$ \\
TLC (thousand/cu.mm.) & $9.82^{* *} \pm 1.20$ & $9.18^{* *} \pm 0.79$ & $9.28^{* *} \pm 0.90$ & $9.79^{* *} \pm 1.11$ \\
Day 28 & & & & \\
TEC (million/cu.mm.) & $9.11^{* *} \pm 0.86$ & $9.36^{*} \pm 0.65$ & $8.89^{* *} \pm 0.58$ & $8.64 \pm 0.59$ \\
Hb content (gm \%) & $10.93^{* *} \pm 0.99$ & $11.07^{* *} \pm 0.939$. & $33^{* *} \pm 0.78$ & $8.13^{* *} \pm 0.48$ \\
PCV (\%) & $32.83^{* *} \pm 1.47$ & $33.67^{* *} \pm 0.82$ & $31.50 \pm 1.05$ & $30.33^{* *} \pm 1.75$ \\
TLC (thousand/cu.mm.) & $9.72^{* *} \pm 1.19$ & $9.11^{* *} \pm 0.74$ & $9.38^{* *} \pm 0.92$ & $10.08^{* *} \pm 1.04$ \\
\hline
\end{tabular}

Table 3. Changes in biochemical parameters in cattle at different intervals after treatment with garlic, turmeric and betel leaf

\begin{tabular}{|clllll|}
\hline \multicolumn{2}{|c|}{ Days after treatment } & $\begin{array}{l}\text { Garlic } \\
\text { Treatment } \\
\text { (Group A) }\end{array}$ & $\begin{array}{l}\text { Turmeric } \\
\text { treatment } \\
\text { (Group B) }\end{array}$ & $\begin{array}{l}\text { Betel leaf } \\
\text { treatment } \\
\text { (Group C) }\end{array}$ & $\begin{array}{l}\text { Untreated } \\
\text { infected control } \\
\text { (Group D) }\end{array}$ \\
\hline Day 0 & ALT (U/l) & $20.40 \pm 2.63$ & $18.98 \pm 1.80$ & $18.32 \pm 1.62$ & $17.97 \pm 2.21$ \\
& AST (U/l) & $32.33 \pm 2.78$ & $31.00 \pm 1.85$ & $30.28 \pm 1.49$ & $29.68 \pm 2.60$ \\
Day 3 & ALT (U/l) & $19.88 \pm 1.73$ & $20.37 \pm 1.48$ & $18.42 \pm 1.74$ & $18.22 \pm 1.57$ \\
& AST (U/l) & $33.05 \pm 2.08$ & $31.58 \pm 2.17$ & $31.15 \pm 1.99$ & $29.67 \pm 2.44$ \\
Day 10 & ALT (U/l) & $19.78 \pm 1.60$ & $19.72 \pm 2.29$ & $17.87 \pm 1.00$ & $18.13 \pm 2.25$ \\
& AST (U/l) & $32.00 \pm 3.29$ & $31.00 \pm 2.04$ & $30.77 \pm 2.45$ & $30.87 \pm 2.02$ \\
Day 17 & ALT (U/l) & $19.55 \pm 3.28$ & $19.73 \pm 2.26$ & $18.67 \pm 1.43$ & $17.33 \pm 2.54$ \\
& AST (U/l) & $31.30 \pm 1.53$ & $31.18 \pm 1.63$ & $31.13 \pm 2.19$ & $29.27 \pm 2.27$ \\
Day 28 & ALT (U/l) & $19.85 \pm 2.50$ & $18.00 \pm 2.16$ & $18.53 \pm 2.32$ & $18.65 \pm 1.96$ \\
& AST (U/l) & $31.45 \pm 2.02$ & $30.88 \pm 1.92$ & $29.67 \pm 2.29$ & $30.90 \pm 2.16$ \\
\hline
\end{tabular}

The above values represent the mean \pm standard deviation (SD) of 6 cattle, ** = Significant at 1 per cent level $(\mathrm{p}<0.01)$, * = Significant at 5 per cent level $(\mathrm{p}<0.05)$. 
Gastrointestinal nematodes in cattle

Table 4. Effects of garlic, turmeric and betel leaf on body weight (Kg) in cattle

\begin{tabular}{|cclllll|}
\hline Group & Treatment & $\begin{array}{l}\text { Pre-treatment } \\
\text { '0' day }\end{array}$ & \multicolumn{2}{l}{ Post-treatment } \\
\cline { 3 - 6 } & & & $3^{\text {rd }}$ day & $10^{\text {th }}$ day & $17^{\text {th }}$ day & $28^{\text {th }}$ day \\
\hline A & Garlic & 124.08 & 124.25 & $124.66^{* *}$ & $125.50^{* *}$ & $126.08^{* *}$ \\
& & \pm 3.71 & \pm 3.62 & \pm 3.60 & \pm 3.77 & \pm 3.71 \\
B & Turmeric & 128.33 & 128.50 & $128.91^{* *}$ & $129.25^{* *} \pm$ & $129.50^{* *}$ \\
& & \pm 4.33 & \pm 4.32 & \pm 4.24 & 4.30 & \pm 4.12 \\
C & Betel leaf & 128.33 & $129.17^{* *}$ & $129.58^{* *}$ & $129.33^{*}$ & 129.00 \\
& & \pm 4.89 & \pm 4.86 & \pm 4.95 & \pm 5.06 & \pm 4.91 \\
D & Control & 125.50 & $125.25^{*}$ & $123.83^{*}$ & $123.17^{* *}$ & $122.92^{* *}$ \\
& & \pm 2.65 & \pm 2.50 & \pm 3.24 & \pm 2.98 & \pm 2.63 \\
\hline
\end{tabular}

The above values represent the mean \pm standard deviation (SD) of 6 cattle, $* *=$ Significant at 1 per cent level $(\mathrm{p}<0.01)$, * = Significant at 5 per cent level $(\mathrm{p}<0.05)$.

\section{REFERENCES}

1. Akhtar MS, Iqbal Z, Khan MN and Lateef M (2000). Anthelminitic activity of medicinal plants with particular reference to their use in animals in the Indo-Pakistan subcontinent. Small Ruminant Research 38: 99-107.

2. British Veterinary Codex (1953). British Veterinary Codex. The Pharmaceutical Press, London, p. 189.

3. Deneke U and Rittersdorf W (1984). Evaluation of the Refloquant GPT (ALT) reagent carriers with Reflotron. Clinical Chemistry 30: 1009.

4. Deneke U, Rittersdorf W and Werner W (1985). Performance data of Reflotron-GOT (AST) dry chemistry test for Reflotron. Clinical Chemistry 31: 921.

5. Farnsworth NR, Akerele O, Bingel AS, Soejarto DD and Guo Z (1985). Medicinal plants in therapy. Bulletine of World Health Organization 63: 965-981.

6. Kaemmerer K and Butendotter S (1973). The problem of residues in meat of edible domestic animals after application or intake of organophosphate esters. Residure Review 46:1.

7. Lans C and Brown G (1998). Ethnoveterinary medicines used for ruminants in Trinidad and Tobago. Preventive Veterinary Medicine 35: 149-163.

8. McLeod RS (1995). Costs of major parasites to the Australian livestock industries. International Journal of Parasitology 25: 1363-1367.

9. Mostofa M. and Amin MR (2005). Comparative efficacy of 4 indigenous medicinal plants against gastro-intestinal nematodiasis in sheep. BAU Research Progress 15: 4.

10. Preston JM and Allonby EW (1979). The influence of breed on the susceptibility of sheep of Haemonchus contortus infection in Kenya. Research in Veterinary Science 26: 34-139.

11. Qadir ANMA (1981). An observation on the seasonal influence on the gastro-intestinal nematode infection in goats under farm conditions. Bangladesh Veterinary Journal 15(3-4): 11-15.

12. Rahman M (2002). In vitro and in vivo anthelmintic effects of some plants against gastro-intestinal nematodes of goats. MS Thesis, submitted to the Department of Parasitology, Bangladesh Agricultural University, Mymensingh.

13. Rahman MH and Mondal MMH (1983). Helminth parasites of cattle (Bos tauras) in Bangladesh. Indian Journal of Parasitology 7: 173-174.

14. Rahman MH, Ahmed S and Mondal MMH (1996). Introduction to helminth parasites of animals and birds in Bangladesh. $1^{\text {st }}$ edn., Sheba Printing Press, Bangladesh, p. 16-17.

15. Samad MA (2001). Poshu Palon O Chikitsavidya. $2^{\text {nd }}$ edn., LEP Publication, Bangladesh, p. 281.

16. Soulsby EJL (1986). Helminth, Arthropod and Protozoa of Domesticated Animals. $7^{\text {th }}$ edn., Bailliere and Tindall, London. pp.763-766.

17. Waller PJ and Prichard RK (1985). Drug resistance in nematodes. In: Campbell, W.C., Rew, R.S. (Eds), Chemotherapy of Parasitic Infections. Phenum, New York, USA, pp. 339-362.

18. WHO (1993). Summary of WHO guidelines for assessment of Herbal Medicines. Herbal Gram 28: 13-14. 